NBER WORKING PAPER SERIES

\title{
CHILD LABOR: THE ROLE OF INCOME VARIABILITY AND ACCESS TO CREDIT ACROSS COUNTRIES
}

\author{
Rajeev H. Dehejia \\ Roberta Gatti \\ Working Paper 9018 \\ http://www.nber.org/papers/w9018
NATIONAL BUREAU OF ECONOMIC RESEARCH
1050 Massachusetts Avenue
Cambridge, MA 02138
June 2002

We thank Jagdish Bhagwati, David Dollar, and Alan Krueger for helpful conversations, Kathleen Beegle, Maria Solededad Martinez Peria, Antonio Spilimbergo and seminar participants at the World Bank and the Inter-American Development Bank for useful comments, and Sergio Kurlat for excellent research assistance. All errors are our own. Dehejia thanks the National Bureau of Economic Research and the Industrial Relations Section, Princeton University, for their kind hospitality. Address correspondence to rd247@columbia.edu. The views expressed herein are those of the authors and not necessarily those of the National Bureau of Economic Research, the World Bank or its member countries.

(C) 2002 by Rajeev H. Dehejia and Roberta Gatti. All rights reserved. Short sections of text, not to exceed two paragraphs, may be quoted without explicit permission provided that full credit, including $\odot$ notice, is given to the source. 
Child Labor: The Role of Income Variability and Access to Credit Across Countries

Rajeev H. Dehejia and Roberta Gatti

NBER Working Paper No. 9018

June 2002

JEL No. J22, G1, O16

\begin{abstract}
This paper examines the relationship between child labor and access to credit at a cross-country level. Even though this link is theoretically central to child labor, so far there has been little work done to assess its importance empirically. We measure child labor as a country aggregate, and credit constraints are proxied by the extent of financial development. These two variables display a strong negative relationship, which we show is robust to selection on observables (by controlling for a wide range of variables such as GDP per capita, urbanization, initial child labor, schooling, fertility, legal institutions, inequality, and openness, and by allowing for a nonparametric functional form), and to selection on unobservables (by allowing for fixed effects). We find that the magnitude of the association between our proxy of access to credit and child labor is large in the sub-sample of poor countries. Moreover, in the absence of developed financial markets, households appear to resort substantially to child labor in order to cope with income variability. This evidence suggests that policies aimed at widening households' access to credit could be effective in reducing the extent of child labor.
\end{abstract}

Rajeev Dehejia

Department of Economics and SIPA

Columbia University

420 W. 118th Street, Room 1022

New York, NY 10027

and NBER

rd247@columbia.edu
Roberta Gatti

Development Research Group

The World Bank, MC3-353

1818 H Street, NW

Washington, DC 20433

rgatti@worldbank.org 


\section{Introduction}

Child labor is a troubling phenomenon. It has been a concern of policy since at least the $19^{\text {th }}$ Century (see Basu (1999), Section 2.2), and the debate on which policies should be employed to reduce it - ranging from legislative bans on child labor, to trade sanctions against countries that use child labor, to schooling subsidies for children - is longstanding. As troubling as child labor is per se, it is essential to investigate its economic determinants in order to inform policy choices and identify their welfare implications.

The evidence and existing literature suggest a strong link between child labor and poverty (Krueger (1996)). In 1995 there were an estimated 120 million children engaged in full-time paid work (see ILO (1996)). In the same year, the incidence of child labor was $2.3 \%$ among countries in the upper quartile of GDP per capita, and 34\% among countries in the lowest quartile of GDP per capita. If this link is causal and there are no market inefficiencies, we would expect promoting general economic development to reduce child labor. However, other mechanisms can also account for the observed relationship between child labor and poverty. In particular, market failures - which are arguably more common where poverty is widespread - or externalities might be the actual cause of child labor. For example, if private returns to education are lower than social returns, child labor can be inefficiently high. In this case, government intervention in the specific market where the inefficiency occurs is to be preferred (Grootaert and Kanbur, (1995)).

The work in this paper goes in this direction. We explore the nexus between child labor and one possible source of inefficiency - the presence of borrowing constraints. By providing evidence that child labor arises in response to a particular form of inefficiency, this work indicates that the issue of child labor can be in part addressed independently of solving the (more complex) problem of general economic development.

At the household level, child labor arises from an inter-temporal trade-off. By entering the job market at an early age, an individual can make an immediate contribution to household income and perhaps gain labor market experience. This addition to earnings potentially carries a long-term cost to the extent that the time children spend working could be used instead in activities that build up their long-run human capital. The nature 
of this cost depends on the alternatives to child labor, such as schooling or time spent in play (which also contributes to cognitive development). The key economic variable that allows households to make this trade-off optimally is access to credit - households can borrow against future income and can also smooth earnings shocks without recourse to child labor.

Even though access to credit is central to child labor theoretically, there has been little work done to assess its importance empirically (see Brown, Deardorff, and Stern (2001)). In this paper, we pursue a cross-country strategy. We measure child labor as a country aggregate, and credit constraints are proxied by the extent of financial intermediation. These two variables display a strong negative (unconditional) relationship (see Figure 1). Of course to determine the strength of the relationship we must control for other important variables. The existing literature on child labor provides some guidance. As noted in most empirical studies on child labor, income is a crucial variable, since regardless of access to credit child labor is strongly associated with poverty. Likewise, the literature suggests that schooling, fertility patterns, ruralization, and openness might be important determinants of child labor. Our results show a strong link between child labor and access to credit even when these factors are accounted for and a range of estimation techniques is used. This relationship appears to be particularly sizeable in the sample of poor countries, which have both less developed financial markets and greater child labor and, as such, are in general of greater policy interest. Moreover, we find that income variability has a sizeable impact on child labor in countries where financial markets are underdeveloped, suggesting that households resort to their children's work to cope with income shocks. This is not the case though when financial markets are developed, which suggests that access to credit might effectively cut households' demands on children's time.

The importance of this result is twofold. First, it establishes the empirical relevance of a significant strand of the theoretical literature on child labor. Second, it clearly points at a policy mechanism that might help alleviate the problem of child labor.

The paper is organized as follows. Section 2 reviews the relevant literature. Section 3 describes the data and presents our results. Section 4 examines the robustness of our results. Section 5 concludes. 


\section{Review of the Literature}

The empirical literature on child labor is vast (see Brown, Deardorff, and Stern (2001)), and the more recent theoretical literature is also substantial (see Basu (1999)). In this section, we highlight the papers that are essential to our empirical strategy.

\subsection{The Modeling Framework}

Basu (1999) partitions the theoretical literature into two groups - papers that examine intra-household bargaining (between parents, or parents and children) and those that examine extra-household bargaining (where the household is a single unit and bargains with employers). Both frameworks are potentially valid for our analysis, and suggest different factors that might influence child labor.

In the intra-household bargaining framework, child labor is the outcome of a bargaining process between members of the household, for example parents and children (see Bourguignon and Chiappori (1994) and Moehling (1995)) or the father and the mother (who is assumed to care for the children more than the father, see Galasso (1999)). The weight that each member receives can depend upon his or her contribution to the family's resources. Collectively, child labor may be desirable because it contributes to the family income, and it may be desirable to the child because it increases his or her weight in the family decision function. Within this framework the key variables are those that determine the relative bargaining strength of different members of the household. This could include wealth, the number, age, and gender of children, and earnings (wages) if an individual were to work (regardless of whether this is observed or not).

The extra-household bargaining framework considers each household as a unitary entity (see, amongst others, Becker (1964) and Gupta (1998)). The motivation behind this approach is that children's bargaining power is inherently very limited, so that parents determine to what extent a child works without necessarily considering the child's welfare. ${ }^{1}$ The parents and the employer bargain about the child's wage and the fraction of

\footnotetext{
${ }^{1}$ However, if parents are altruistic, they face a meaningful trade-off between the benefit of child labor and its cost. We will discuss this mechanism in detail in Section 2.2.
} 
that wage to be paid as food to the child. Within this framework the key variables are those that determine the relative bargaining strength of the household vis à vis the employer. These also include household wealth variables as well as access to credit.

\subsection{The Role of Access to Credit}

The role of credit markets in determining the extent of child labor has been addressed by a recent strand of the theoretical literature (Parsons and Goldin (1989), Baland and Robinson (2000), Ranjan (1999, 2001) and Rosati and Tzannatos (2000)). Analytically this question is closely related to the literature on bequests within altruistic, unitary models of the family à la Becker (1974). That literature has highlighted that the non-negativity constraint in bequests can lead to an inefficient allocation of resources within the family (see for example Becker and Murphy (1988)). In particular, if parents care about their children but bequests are at a corner, child labor is not generally efficient. The basic intuition is that child labor creates a trade-off between current and future income. Putting children to work raises current family income, but by interfering with children's human capital development, it reduces future income. This future income is, of course, realized by the children and not the parents. Thus, if there are positive bequests, parents can compensate themselves for foregone current income by reducing bequests. Conversely, if bequests are at a corner - which is more likely to occur for poorer households - parents will tend to draw on child labor too heavily.

Even if conditions exist for an efficient allocation of child labor from an intergenerational perspective (i.e., bequests are positive), parents might still choose an inefficiently high level of labor for their children if they cannot borrow to smooth their consumption over time, i.e. if the intragenerational allocation of resources is constrained. The following model, adapted from Baland and Robinson (2000), illustrates this point analytically.

Consider a two-period model where the parent and the child live contemporaneously. In each period the parent supplies labor inelastically, earning income $A$. In period 1 , the parent decides how much to save for the following period, $s$, as well as the extent to which his child will work, $l_{c} \in[0,1]$. When working in period 1 , the child 
earns $l_{c}$, which the parent can appropriate completely. In period 2, the child, now an adult, will supply one unit of labor, which will earn her an income of $h\left(1-l_{c}\right)$, where $h$ is the human capital accumulated in period $1 . h(\cdot)$ is decreasing in $l_{\mathrm{c}}$ and is strictly concave, with $h(0)=1$.

We assume that the parent is altruistic. He cares about his own consumption in periods 1 and 2, $c_{p}^{1}$ and $c_{p}^{2}$ respectively, and, to the extent $\lambda$, about the child's utility. Because of altruism, in period 2 the parent might want to leave a bequest $b$ to the child.

For simplicity, parental utility is additively separable and there is no intertemporal discount. The child is selfish and cares only about her own consumption $c_{c}$ (for further simplicity, the child only consumes in period 2).

The parent's utility function is

$$
W_{p}=u\left(c_{p}^{1}\right)+u\left(c_{p}^{2}\right)+\lambda W_{c}\left(c_{c}\right)
$$

where $W_{c}\left(c_{c}\right)$ is the child's utility function and $u(\cdot)$ and $W_{i}(\cdot)$ are concave and wellbehaved functions.

The parent's budget constraints in periods 1 and 2 are:

$$
c_{p}^{1}=A+l_{c}-s
$$

and

$$
c_{p}^{2}=A-b+s .
$$

The child's budget constraint is

$$
c_{c}=h\left(1-l_{c}\right)+b .
$$

In order to illustrate how inefficiently high child labor might emerge if individuals cannot borrow, we focus on the case where $s \geq 0 .{ }^{2}$ The first order conditions are as follows:

(1) with respect to $b$

$$
\begin{array}{ll}
u^{\prime}\left(c_{p}^{2}\right)=\lambda W_{c}^{\prime}\left(c_{c}\right) & \text { if } b>0 \\
u^{\prime}\left(c_{p}^{1}\right) \geq u^{\prime}\left(c_{p}^{2}\right) & \text { if } s \geq 0 \\
u^{\prime}\left(c_{p}^{1}\right)=\lambda W_{c}^{\prime}\left(c_{c}\right) h^{\prime}\left(1-l_{c}\right) &
\end{array}
$$$$
\text { (2) with respect to } s
$$$$
\text { (3) with respect to } l_{c}
$$ 
In this setup, the chosen level of child labor is efficient when the marginal return to time spent in school equals its marginal cost (the opportunity cost of child labor). Here the return to education is $h\left(1-l_{c}\right)$ and the opportunity cost of child labor is $l_{c}$. Efficient child labor is therefore defined by $h^{\prime}\left(1-l_{c}\right)=1$. Conversely, child labor is inefficiently high if $h^{\prime}\left(1-l_{c}\right)>1$. Baland and Robinson (2000) show that if $s=0$ (i.e. if the borrowing constraint is actually binding), the parent will choose to make his child work too much. If in period 1 the parent wished he could borrow but cannot do so, his consumption will be lower and its marginal utility higher than optimal, $u^{\prime}\left(c_{p}^{1}\right)>u^{\prime}\left(c_{p}^{2}\right)$. Substituting for $u^{\prime}\left(c_{p}^{2}\right)$ from (1) and $u^{\prime}\left(c_{p}^{1}\right)$ from (3), it easily follows that $h^{\prime}\left(1-l_{c}\right)>1$. Intuitively, if the parent cannot smooth consumption between period 1 and 2 through borrowing, he will use child labor to increase consumption in period 1 at the expense of his child's human capital accumulation.

This model suggests that the availability of credit should be a factor that predicts the incidence of child labor. Moreover, if such an effect is found, it will provide evidence that the child labor we observe is in fact inefficient. Since our empirical work is at the aggregate level, we will use the degree of development of financial markets in a country as a measure of the credit constraints that individuals face.

\subsection{Empirical Work}

At the level of micro data, there is a range of empirical studies that examine the causes of child labor. In a recent volume, Grootaert and Patrinos (1999) review findings from Côte D'Ivoire, Colombia, Bolivia, and the Philippines. Other authors have examined child labor in Ghana (Canagarajah and Coulombe (1997)) and Vietnam (Edmonds and Pavcnik (2001)). A consistent finding is that child labor is associated with poverty. This, of course, is what we would anticipate, and it underlines the necessity of controlling for income in our empirical analysis. Among other determinants of child labor

\footnotetext{
${ }^{2}$ For simplicity, we allow only transfers from the parent to the child and derive first order conditions under the assumption that $b>0$.
} 
at the individual level are the child's age and gender, education and employment of the parents, and rural versus urban location. From this list, it is of course difficult at the aggregate level to control for household-specific attributes such as gender composition and age, but we can control for education and the degree of urbanization of a country.

At the cross-country level, much work has gone into creating a uniform definition of child labor. Two significant efforts in this direction are Ashagrie (1993) and Grootaert and Kanbur (1995). These previous analyses are more concerned with measuring the extent of child labor than with estimating the effect of various country characteristics on the degree of child labor. Krueger (1996) establishes a strong negative relationship between the prevalence of child labor and national income, a finding which is confirmed in the present study. Krueger also shows that there is little evidence (at least in the United States) that the support for banning imports made with child labor is linked to the potential benefits to domestic rent seekers (i.e., unskilled labor, who might benefit from such a ban).

Although (to our knowledge) the link between access to credit and child labor has not been examined directly, it has been examined indirectly in two ways. First, the literature on the causes of child labor has noted a link between household assets and child labor (see Grootaert and Patrinos (1999) and Brown, Deardorff, and Stern (2001)). To the extent that assets can serve as collateral for borrowing, this link suggests that access to credit might play a role. Of course, the evidence is indirect, and might also be picking up wealth effects. Second, there are some significant papers that examine the link between credit and schooling choices. Jacoby and Skoufias (1997) examine the completeness of credit markets in a dataset of six Indian villages. They find that households are not fully able to insure themselves against unanticipated idiosyncratic income shocks, and as a result reduce schooling. Jacoby (1994), using data from Peru, finds that children in households with lower levels of income and durable goods (consequently, presumably with a lower access to credit) are more likely to repeat grades at school. Flug, Spilimbergo, and Wachtenheim (1998) examine the effect of financial development on schooling using cross-sectional country data, and find a negative and significant effect. These papers are complementary to the present study, because - as shown by Ravallion 
and Wodon (1999) for data from Bangladesh - schooling and child labor are not one-forone substitutes.

\section{Data, Specification, and Results}

The availability of child labor data (see below) allows us to build a panel for 172 countries for the years 1950-60, 70, 80, 90, 95. For this dataset we first estimate a parsimonious specification where we control for some basic determinants of child labor. We then add to this specification our variable of interest (a proxy for the availability of credit within a country), and investigate whether access to credit is effective in dampening risk by adding to the specification a measure of income volatility. In the next section, we perform a number of robustness checks, which include estimating our specification without outliers, adding to the regression a number of other variables that, if not accounted for, might generate an omitted variable problem, and allowing for fixed effects and flexible functional form.

\subsection{Data description}

We measure the extent of child labor (CHILDLAB) as the percentage of the population in the 10-14-age range that is actively engaged in work. These data were compiled by the ILO and are available at ten-year intervals starting from 1950 for 172 countries. "Active population" includes people who worked (for wage or salary, in cash or in kind as well as for family unpaid work) for at least one hour during the reference period (ILO (1996)). The structure of the data does not allow us to infer the intensity of child labor, so that we cannot distinguish between light child work (that some might argue to be beneficial for adolescents) and full-time labor that might seriously conflict with human capital accumulation. Moreover, like most official data on child labor, these data are likely to suffer from underreporting, as work by children is illegal or restricted by law in most countries and children are often employed in the informal sector. These problems notwithstanding, the ILO data has the advantage of being adjusted on a basis of 
the internationally accepted definitions, thereby allowing cross-countries comparisons (Ashagrie (1993)).

As a proxy for the absence of credit constraints we use the ratio of private credit issued by deposit-money banks to GDP (the variable CREDIT, which we refer to interchangeably as "access to credit" or "financial development"). This variable isolates credit issued to the private sector (as opposed to credit issued to governments and public enterprises) and captures the degree of activity of financial intermediaries that is most relevant to our investigation: the channeling of savings into lending (Beck, DemirgucKunt, and Levine (1999)). Using data on nearly 3,000 small and medium firms and 48 countries from the World Business Environment Survey dataset, Beck, Demirguc-Kunt and Maksimov (2002) show that this credit variable is negatively and significantly correlated with the degree of firms' financing constraints (a correlation of -0.20 , significant at $1 \%)^{3}$ To the extent that small and medium enterprises face financing problems similar to those of households, this lends support to our use of this proxy. However, it also underlines the fact that financial intermediation has an effect not only on households, but also on the producer side of the economy. As such our access to credit proxy embodies both of these effects, and can be interpreted more broadly as capturing the effect of financial development (see King and Levine (1993) and Rajan and Zingales (1998)).

Figures 2 and 3 graph, respectively, the incidence of child labor in different regions of the world and the evolution of child labor and credit over time. The two variables are plotted in Figure 1. To proxy for economic volatility we follow Flug et al. (1999) and construct the standard deviation of annual per capita income growth rates in the previous 5 (and 10) years. We expect that more children enter the labor force when economic volatility is high, all the more so if financial institutions are underdeveloped and credit cannot be used by families to smooth consumption over time.

The various specifications account for a number of other controls, including linear and squared log GDP per capita (LRGDPPC and LRGDPPC2), percentage of rural population (RURAL), continent dummies, share of imports (IMP) and exports (EXP) of

\footnotetext{
${ }^{3}$ More precisely, it is correlated with enterprise managers' perceptions about how large an obstacle financing issues are for their business. For more details, see Beck et al. (2002).
} 
GDP, fertility (FERTILITY), the ratification of the 1973 Geneva convention on child labor (RATIFY), origin of the legal system (LEGAL ORIGIN), and income inequality (GINI). All of the variables and their sources are described in the Appendix. In Section 4 , we discuss in detail the possible bias that excluding each variable might generate in the estimated coefficient on credit. Tables 1 and 2 report averages of and correlations among the variables.

\subsection{Basic Specification}

The empirical literature on child labor uniformly indicates that income is the single most important household-level predictor of child labor (in general, the children of poor families are more likely to work). It seems reasonable to expect that income is an important determinant of child labor at the aggregate level as well. To control for this effect we include in our specification (the log of) per capita income and allow for linear and quadratic terms (LRGDPPC and LRGDPPC2).

Child labor is highly correlated over time. The correlation between child labor in 1950 and child labor in 1980 is around 0.9. Consequently it is important to control for initial conditions, and we include the level of child labor in 1950 (CHILD50) in our specification. In some sense, including child labor in 1950 amounts to controlling for a country-specific effect, and purges to some extent the spurious cross-sectional correlation that is often problematic in cross-country regressions. (In Section 4.2 we address this issue more directly, by allowing for fixed effects.) We also include in the equation the percentage of rural population to control for the fact that in developing countries (and also historically in developed countries) child labor is strongly associated with agricultural work. Finally, we allow for a time trend.

The baseline specification is therefore:

Child labor $_{i t}=f\left(\right.$ constant, time trend $_{t}, \log$ real GDP per capita ${ }_{i t}, \log$ real GDP per capita $_{i t}^{2}$, percentage of rural population ${ }_{i t}$, child labor in $1950_{i}$ ) 
We first estimate the equation using OLS. The results are reported in Table 3, column (1). Both income terms are highly significant, with child labor reaching a minimum at a per capita income of $\$ 2,891$. As anticipated, initial child labor is highly significant. Rural population turns out to be significant only at the 10 per cent level. Finally, the time trend is negative and significant.

One important feature of data on child labor is the presence of a substantial proportion of zeros. Of the 703 data points used in column (1), over 20 percent are zero. The OLS assumption of linearity (and implicitly normality for the standard errors) might not be appropriate in this context. Thus, we also present results for a Tobit estimate. In column (4), we see that the sign of the coefficients is the same, but the magnitude of the impacts differ somewhat. Since the Tobit specification accounts for the mass point in the outcome distribution and is potentially less sensitive to outliers in the data, the Tobit specification seems to be more appropriate. As a robustness check, we present both sets of estimates throughout the paper.

\subsection{The availability of credit}

We now introduce our measure of credit availability into the basic specification. The OLS results for the estimation in the full sample are presented in Table 3, column (2). Credit enters with the expected sign (negative - as the aggregate availability of credit increases, the prevalence of child labor decreases), and is statistically significant, even after controlling for income, initial child labor, rural population, and a time trend. When using a Tobit specification, the coefficient on credit is more than twice as large as OLS and strongly significant. ${ }^{4}$

As a test of robustness we exclude outliers from the regressions. With 474 observations and 135 countries, extreme observations might in principle be quite influential. We employ the Hadi (1992) selection criterion for outliers in multivariate regressions. ${ }^{5}$ Four countries (Myanmar, Hong Kong, Switzerland, and Zaire) are

\footnotetext{
${ }^{4}$ Throughout the paper, we report marginal coefficients for Tobit.

${ }^{5}$ Hadi's (1992) technique is particularly useful to identify outliers in a multivariate regression setting and is based on a procedure that recursively defines distance of an observation from a cluster of observations in the model.
} 
identified as outliers in this context. We rerun the OLS and Tobit specifications without these outliers. For OLS the magnitude of the coefficient of credit increases by $30 \%$, and the estimate is even more significant. For the Tobit, the magnitude and significance of the marginal coefficient are unaffected.

We then estimate our specification for the sub-samples of rich and poor countries (where we split the data by mean GDP per capita). This is a natural dimension along which to search for heterogeneity in the effect of credit. We would imagine the effect to be greater for poorer countries, where improvements in access to credit are presumably extending the basic infrastructure of financial markets. Instead the effect of access to credit in richer countries is presumably higher-order and less likely to affect households. This is confirmed by our results in Table 4, for both the OLS and Tobit specifications. The effect of credit is significant in both sub-samples but is several orders of magnitude larger in poor countries than in rich countries.

The magnitude of the estimated coefficient in the full sample is small, relative for example to the effect of GDP per capita. For the OLS estimates, a one standard deviation increase in access to credit is associated with a decrease of five per cent of a standard deviation in child labor. For Tobit, a one standard deviation increase in access to credit is associated with more than ten per cent of a standard deviation decrease in child labor. In contrast, the magnitude of the effect of GDP per capita is much larger. If a country were to move from the $5^{\text {th }}$ to the $10^{\text {th }}$ percentile of GDP per capita in 1995 (i.e., from $\$ 504$ to $\$ 618$ ), child labor would decrease by 3 to 5.5 percentage points, on a base prevalence of child labor of $39 \%$ for that level of income. In contrast, moving between the same percentiles of access to credit would lead only to a 0.05 to 0.1 percentage point decrease in child labor. Nonetheless, it is plausibly easier to increase household access to credit than to induce general economic development, so it might be reasonable to consider larger increases in the level of access to credit. ${ }^{6}$ For example, a move from the $25^{\text {th }}$ to the $75^{\text {th }}$ percentile of access to credit would bring about a 1 to 2.4 percentage point decrease in child labor.

\footnotetext{
${ }^{6}$ More precisely, though it is also difficult to increase the level of financial development of a country, it is presumably easier to increase household access to credit, which is the underlying variable of interest, for example by targeting credit to poorer households with children.
} 
Moreover, for the countries of greatest policy interest - poorer countries, which have both a lower level of financial development and higher child labor - the magnitude of the effect is much larger. A move from the $25^{\text {th }}$ to the $75^{\text {th }}$ percentile of access to credit in a poor country is associated with a 4.2 percentage point decrease in child labor. ${ }^{7}$

\subsection{The effect of income variability}

Our results confirm that the availability of credit - as proxied by financial development - plays a significant role in explaining child labor. However, there are several pathways through which this effect could operate. Table 3 does not shed light on which mechanisms are empirically relevant. Access to credit obviously has an effect economic growth and long-run income, but by controlling for the level of GDP per capita, we are accounting for this effect to some extent. In Table 5, we explore another possible mechanism - smoothing income shocks.

As outlined in Section 2, families might resort to sending their children to work to help them cope with negative income shocks. Nonetheless, if credit is widely available, households can borrow to smooth income variability and might not need to disrupt their children's education (or leisure time). When we introduce our measure of income volatility (SDGROW5, the standard deviation of annual GDP growth in the previous 5 years) into the specification, we see that the estimated coefficient is large and highly significant, suggesting that households indeed use child labor to cope with income volatility. ${ }^{8}$ In principle, though, the variability of income should affect child labor mostly in those countries where credit is not accessible. To investigate this possible effect, we split the sample into high and low credit groups, using the mean as the cutoff. In Table 5, column (2) (column (5), for Tobit), we see that for the low credit group, income variability enters the specification significantly and the magnitude of the coefficient is

\footnotetext{
${ }^{7}$ Not surprisingly, when we split the sample by level of income, quadratic income loses its significance in three out of four specifications. The size and significance of the coefficient on CREDIT remain virtually unchanged if we exclude the quadratic term in income and control only for linear income.

${ }^{8}$ Results are virtually the same when instead of SDGROW5 we use SDGROW10, the standard deviation of annual GDP growth in the previous 10 years.
} 
substantial. Instead, for the high credit group (columns (3) and (6)), the effect of income volatility on child labor is small and not significantly different from zero. ${ }^{9}$

\section{Robustness checks}

A significant concern regarding our results in Section 3, and more generally a concern regarding all cross-country regressions, is whether the effect of credit availability on child labor is truly causal. To be confident of identifying a causal effect we must control for factors - both observed and unobserved - that influence selection into a particular level of credit availability. Because of the interrelatedness of macro-level variables, this is an inherently difficult condition to satisfy. We extend the empirical framework in three directions to check for the robustness of our results. First we consider additional control variables (hence examine sensitivity to selection on observables). Second, we consider fixed-effects models (hence examine sensitivity to selection on unobservables). Third, we consider propensity score estimates (a nonparametric estimator which considers sensitivity to functional form selection).

\subsection{Additional Controls}

We now subject our result to a battery of additional controls. Our interest is not to interpret the additional coefficients causally, since some of the variables we add are potentially endogenous with respect to child labor. The additional controls are intended instead to confirm that the significance of credit is not simply attributable to omitted variable bias. Estimates are reported in Table 6 (for OLS) and Table 7 (for Tobit).

First, we add continent dummies. When estimated with OLS, the magnitude of the credit variable decreases, and it is no longer statistically significant at the conventional level, while the magnitude and significance of credit are not substantially affected in the Tobit estimation (Tables 6 and 7, column (1)). In both the OLS and Tobit estimates, the coefficient on the Sub-Saharan Africa dummy is positive and significant, suggesting that the high prevalence of child labor in this region is due to factors (cultural, institutional)

\footnotetext{
${ }^{9}$ These estimates do not appear to be sensitive to outliers.
} 
other than income level, prevalence of rural population, and development of financial markets. As an additional robustness check (results not reported), we reestimate the relationship, excluding countries from Sub-Saharan Africa, and find that the credit coefficient remains significant. ${ }^{10}$

We then control for primary and secondary (female) school enrollment (Tables 6 and 7, columns (2) and (3)). At the household level there is a close connection between the prevalence of education and child labor. Over the long run, the availability of education gives rise to an important inter-temporal trade-off in the time allocation of children. Time spent in schoolwork may displace time spent in work, but also creates a stream of future returns to education. Of course, schooling is not a full-time activity, so this tradeoff may not be very extreme - schooling and child labor might co-exist at the expense of leisure activities (see Ravallion and Wodon (1999)). Presumably for secondary schooling the trade-off is more substantial. The empirical results bear out this reasoning. Primary enrollment enters the specification negatively (more schooling, less child labor), but is only marginally significant. Instead, secondary enrollment is negative and highly significant. Because of potential endogeneity problems in the specification with enrollment, these coefficients should not be interpreted causally. Our interest is in the robustness of the credit coefficient. Here we find that the OLS coefficient on credit is smaller (though still significant). The Tobit coefficient is much more robust to the inclusion of schooling controls.

We next control for the level of fertility. Fertility is strongly tied to child labor. Larger, poorer families might need to send their children to work to help support the family. On the other hand, couples might want to have more children if they think that the children can bring a net increase in family income and if child labor is a widespread phenomenon in their community. When fertility is included in the regression, the magnitude of the coefficient on credit in the OLS decreases, and in fact is no longer statistically significant. However, five outlier countries drive this result. ${ }^{11}$ Once these

\footnotetext{
${ }^{10} \mathrm{We}$ also check for robustness to the exclusion of countries from Eastern and Central Europe, because of potential measurement error problems with child labor in former Soviet-bloc countries.

${ }^{11}$ These countries (Myanmar, Hong Kong, Saudi Arabia, Switzerland, and Zaire) are selected using Hadi's (1992) methodology.
} 
countries are excluded, the t-statistic on the credit variable increases to 2.13. Finally, the Tobit estimates of the credit coefficient are robust to the inclusion of fertility.

A potential source of spurious correlation for the credit estimates are legal institutions, which both influence the development of financial intermediation and the enforcement of child labor laws. We proxy for this effect by including dummy variables that identify the historic origins - British, French, etc. - of the countries' legal systems. None of these dummies is significant, individually or jointly. The OLS estimate of the credit variable is marginally weakened while the Tobit coefficient is virtually unaffected (Tables 6 and 7, column (5)).

In order to control more directly for a country's commitment to fight against child labor, we include in the specification a dummy (RATIFY) indicating whether the country has ratified the 1973 ILO convention against child labor - also known as the Minimum Age Convention - which specifies fifteen years of age as the cutoff age for participating in economic activity. ${ }^{12}$ Note that only 93 out of the 207 countries originally in our sample have ratified the convention (the US, for example, is not a signatory to the convention). When RATIFY is included in the regression, the significance of the credit variable is weakened in the OLS specification. However, when four outlier observations are excluded, the credit variable is again significant (at the $10 \%$ level) ${ }^{13}$. Moreover, its significance is unaffected in the Tobit specification (Tables 6 and 7, column (9)). The dummy itself is not significant.

We also consider variables measuring the openness of the economy (exports and imports as percentages of GDP). If "all good things go together", the prevalence of child labor might simply reflect openness of the economies, while, at the same time, more open countries might also be those with more developed financial markets. Moreover, recent microeconomic evidence from Vietnam suggests that "greater market integration appears to be associated with less child labor" (Edmonds and Pavcnik (2001)). Interestingly, import and export shares are not significant. The credit variable remains significant in both sets of estimates.

\footnotetext{
${ }^{12}$ Convention concerning Minimum Age for Admission to Employment no.138, 1973, ILO, Geneva.

${ }^{13}$ Outliers are identified by Hadi's (1992) methodology.
} 
Finally, the degree of income inequality (as measured by the Gini coefficient) could be an important source of spurious correlation in the regression (for example, the correlation table highlights that the Gini coefficient displays a significant unconditional correlation with both child labor and credit). Accounting for inequality does not appear to affect estimate and significance of the coefficient on credit.

Overall, we find that the credit variable is robust to the inclusion of a wide range of controls. Although the magnitude and the significance of the OLS coefficient are sensitive to some of the controls (in particular Sub-Saharan Africa dummy, fertility, and the ratification dummy), estimates from the Tobit specifications are uniformly stable.

\subsection{Selection on Unobservables}

In this section we examine the sensitivity of our estimates to the possibility of selection on unobservables. Because of the panel-data structure of the dataset, we can control for selection on unobservables by including fixed (random) effects in our linear regression (Tobit) model. The fixed effect allows us to control for time-invariant selection effects. We, of course, remain exposed to time-varying omitted variables. Table 8 presents the results.

In column (1) we see that using a fixed-effects model the estimated coefficient of credit in fact changes sign; it is positive and statistically significant. This qualifies our result that increased availability of credit causes a reduction in the prevalence of child labor. In Tables 3 and 7 we noted that the Tobit is less sensitive to changes in specification, because the mass point at zero child labor anchors the estimates. In Table 8, the same holds true. Considering a random-effects Tobit model, the effect is negative for the entire sample period, though smaller in magnitude and not statistically significant.

As in Table 4, it is instructive to consider the estimated effect of credit for the subsamples of poor and rich countries, splitting the sample at mean GDP per capita. The poorer countries are in general of greater policy interest, since they have both less developed financial markets and greater child labor. In Table 8 we see that allowing for fixed (random) effects the estimated effect is negative and significant for the sub-sample of poor countries for the OLS (Tobit) specification, though the magnitude is smaller. The 
effect is positive for richer countries in the OLS specification, and negative and insignificant for the Tobit specification.

Thus, though our result is not robust for richer countries, for poorer countries, which is the group of greater policy interest for child labor issues, the result is robust to the inclusion of country-specific effects.

\subsection{Sensitivity to Functional Form Assumptions: Nonparametric Estimates}

In this section we consider the implications of relaxing the functional form assumptions that are implicit in our regression models. Though we considered higherorder terms of some variables, such as log real GDP per capita, in general one must be cautious about functional form issues, especially when, as in our case, estimates are extrapolated across a highly heterogeneous group of countries. Propensity score estimation (Rosenbaum and Rubin (1983); see also Heckman, Ichimura, and Todd (1997,1998), Dehejia and Wahba (1999, 2002), and Lechner (2002)) offers a nonparametric means to address this concern. Propensity score estimation assumes that there is a discrete (initially binary) treatment, and that selection is based on observable variables. We first estimate the probability of assignment to a "treated" country (i.e., a country with well-developed financial markets) conditional on the observables. Then the

Propensity Score Theorem establishes that, within groups that are homogeneous on the propensity score, the entire distribution of covariates is balanced across the treated and untreated groups. In particular, we use kernel propensity score matching (Heckman, Ichimura, and Todd $(1997,1998)$ ), in which each treated country is matched to the untreated countries according to propensity score distance, weighted using a Gaussian kernel. The results are presented in Table 9.

In the first column, we use our base specification from Table 3 but exclude initial child labor. In the second column we control for initial child labor (in 1950). In the third column we control for lagged child labor. The estimator in the third column is most comparable to fixed effects, more particularly to a first-differences estimator. However, rather than first differencing, by controlling for lagged child labor we consider "quasidifferences". The estimated effect on child labor is negative and statistically significant in 
all three columns. The fact that the quasi-differenced propensity score estimate in column (3) is negative is noteworthy because of its affinity with the fixed effects estimator - by (quasi-) differencing it allows for unobservables, but it also controls for observables flexibly via the propensity score. This suggests that our result is robust to both selection on observables and unobservables, when we control for the observables sufficiently flexibly.

The order of magnitude of the estimate is similar to the estimates in Table 3. In Table 3, the estimated OLS coefficient is -0.033 . If we think of moving from low credit to high credit as moving from the $25^{\text {th }}$ to the $75^{\text {th }}$ percentile of access to credit, then this corresponds to an effect of -0.01 on child labor. In Table 9 the estimates for the binary treatment range from -0.0093 to -0.013 .

A limitation of the results in Table 9 is that they assume a binary treatment, whereas access to credit is a continuous variable. The propensity score methodology can be extended to discrete, multi-valued treatments (see Imbens (2000) and Lechner (2001)). In Table 10 we apply propensity score matching to a multi-valued treatment, with treatment 1 to treatment 4 corresponding to the quartiles of the access to credit variable. The notion of being "treated" is now more nuanced. For example, if a country is initially under treatment 2, greater access to credit corresponds to being exposed to treatments 3 or 4 or a reduced access to credit corresponds to being exposed to treatment 1 . Thus in Table 10, the columns correspond to the treatment to which countries are currently exposed, and in the rows we consider the treatment levels to which they could counterfactually -be assigned.

A priori we imagine that the treatment effects below the diagonal should be negative, since these correspond to moving from a lower- to a higher-credit country. Likewise, above the diagonal, treatment effects should be positive. Inspecting Table 10, we note that this pattern holds: all of the below-diagonal estimates are negative, and all of the above-diagonal estimates are positive. In general the above-diagonal estimates are not precisely estimated; none of the estimates is statistically significant. Among the belowdiagonal terms the largest magnitudes and most significant effects are in row 4. Moving up to the highest level of access to credit has a negative and significant impact on child 
labor. Likewise moving from the second to the third level of access to credit also has a negative and significant impact.

Thus propensity score matching methods confirm the robustness of our result. Even when we allow for a flexible functional form, the effect of credit on child labor is negative and significant. Overall, our robustness checks confirm that this effect is not an artifact of selection on observables, selection on unobservables, nor naïve functional form assumptions.

\section{Conclusion}

In this paper we have investigated the relationship between child labor and access to credit across countries. The theoretical literature has highlighted the importance of this relationship, suggesting that, in presence of credit constraints, (inefficient) child labor might arise whenever parents are prevented from trading off resources intertemporally. Our empirical results confirm the existence of a significant association between child labor and the share of private credit issued by banks to GDP, which we interpret as a proxy of access to credit. This relationship appears to be particularly large in the sample of poor countries, which have both less developed financial markets and greater child labor and, as such, are of greater policy interest. We also provide evidence that strong financial markets dampen the impact of income variability on child labor, which would otherwise be sizeable.

As with most work on cross-country data, caution must be used in interpreting the estimated coefficients causally. There are many potential sources of spurious correlation and selection. We subjected our result to a wide array of robustness checks, including adding a range of controls (linear and squared income, share of rural population, continent dummies, fertility, primary and secondary school enrollment, import and exports shares, and ratification of the 1973 ILO convention on child labor), considering fixed effects, and allowing for a nonparametric choice of functional form. The relationship remains strong under all of these alternatives.

These results are important for two reasons. First, they confirm the empirical relevance of a recent strand of the theoretical literature on child labor. Second, these 
results open an important policy window on alleviating the problem of child labor. Increasing household access to credit can be an effective tool in reducing the extent of child labor, and has distinct advantages over other remedies. Compared to legal restrictions and direct bans, it can decrease child labor without lowering household welfare, and it is arguably simpler and can have a more immediate impact than general economic development. 


\section{REFERENCES}

Ashagrie, Kebebew (1993). "Statistics on Child Labor," Bulletin of Labor Statistics, No. 3. Geneva: International Labor Organization.

Baland, Jean-Marie, and James Robinson (2000). "Is Child Labor Inefficient," Journal of Political Economy, 108, 663-679.

Basu, Kaushik (1999). "Child Labor: Cause, Consequence, and Cure with Remarks on International Labor Standards," Journal of Economic Literature, 37, 1083-1119.

Beck, Thorsten, Asli Demirguc-Kunt and Ross Levine (1999). "A New Database on Financial Development and Structure," World Bank Policy Research Paper No. 2146.

Beck, Thorsten, Asli Demirguc-Kunt and Vojislav Maksimov (2002). "Financing Patterns around the World; the Role of Institutions," mimeo., The World Bank.

Becker, Gary (1964). Human Capital, New York: Columbia University Press.

--- (1974). “A Theory of Social Interactions,” Journal of Political Economy, 82, 1063-93.

--- and Kevin Murphy (1988). "The Family and the State," Journal of Law and Economics, 31, 1-18.

Bhagwati, Jagdish (1995). "Trade Liberalization and 'Fair Trade' Demands: Addressing the Environment and Labor Standards Issues," World Economy, 18, 745-759.

Bourguignon, Francois, and Pierre-Andre Chiappori (1994). "The Collective Approach to Household Behavior," in The Measurement of Household Welfare, Richard Blundell, Ian Preston, and Ian Walker, eds. Cambridge: Cambridge University Press. 
Brown, Drusilla, Alan Deardorff, and Robert Stern (2001). "Child Labor: Theory, Evidence, and Policy," School of Public Policy Discussion Paper No. 474, University of Michigan.

Canagarajah, Roy and Harold Coulombe (1997). "Child Labor and Schooling in Ghana," Human Development Technical Report (Africa Region), The World Bank, Washington.

Central Intelligence Unit. The World Factbook 1995-96. Washington: Brassey's.

Collingsworth, Terry, William Goold, and Pharis Harvey (1994). "Time for a New Global Deal," Foreign Affairs, 73, 8-13.

Dehejia, Rajeev, and Sadek Wahba (1999). "Causal Effects in Non-Experimental Studies: Re-Evaluating the Evaluation of Training Programs," Journal of the American Statistical Association, 94, 1053-1062.

------ and ------ (2002). "Propensity Score Matching Methods for Non-Experimental Causal Studies," Review of Economics and Statistics, 84, 151-161.

Deininger, Klaus and Lyn Squire (1996). “A New Dataset Measuring Income Inequality," World Bank Economic Review, 10, 565-91.

Edmonds, Eric and Nina Pavcnik (2001). "Does Globalization Increase Child Labor? Evidence from Vietnam," mimeo., Darmouth College.

Flug, Karnit, Antonio Spilimbergo and Eric Wachtenheim (1999). "Investment in Education: Do Economic Volatility and Credit Constraints Matter?" Journal of Development Economics, 55, no. 2.

Galasso, Emanuela (1999). "Intra-Household Allocation and Child Labor in Indonesia," mimeo., Boston College. 
Grootaert, Christian, and Ravi Kanbur (1995). "Child Labor: An Economic Perspective," International Labor Review, 134, 187-203.

Grootaert, Christian, and Harry Patrinos (1999). The Policy Analysis of Child Labor: A Comparative Study, New York: St. Martin's Press.

Gupta, Manash (1998). "Wage Determination of a Child Worker: A Theoretical Analysis," forthcoming Review of Development Economics.

Hadi, Ali (1992). "Identifying Multiple Outliers in Multivariate Data," Journal of the Royal Statistical Society. Series B, 54, 761-771.

Heckman, James, Hidehiko Ichimura, and Petra Todd, "Matching as an Econometric Evaluation Estimator: Evidence from Evaluating a Job Training Programme," Review of Economic Studies, 64, 605-654.

--------, --------, and --------, "Matching as an Econometric Evaluation Estimator," Review of Economic Studies, 65, 261-294.

ILO (1996). Economically Active Population: Estimates and Projections, 1950-2010. Geneva.

Imbens, Guido (2000). "The Role of the Propensity Score in Estimating Dose-Response Functions," Biometrika, 87, 706-710.

Jacoby, Hanan (1994). "Borrowing Constraints and Progress Through School: Evidence from Peru," Review of Economics and Statistics, 76, 151-160.

------, and Emmanuel Skoufias (1997). "Risk, Financial Markets, and Human Capital in a Developing Country," Review of Economic Studies, 64, 311-335. 
King, Robert, and Ross Levine (1993). "Finance and Growth: Schumpeter Might Be Right," American Economics Review, 108, 717-737.

Krueger, Alan (1996). "Observations on International Labor Standards and Trade," National Bureau of Economic Research, Working Paper No. 5632.

La Porta, Rafael, Florencio Lopez-de-Silanes, Andrei Shleifer, and Robert Vishny (1998). "The Quality of Government," Journal of Law, Economics, and Organization, $15,222-279$.

Lechner, Michael (2001). "Identification and Estimation of Causal Effects of Multiple Treatments under the Conditional Independence Assumption," in: Lechner, M., Pfeiffer, F. (eds.), Econometric Evaluation of Labour Market Policies, Heidelberg: Physica/Springer, pp. 43-58.

----- (2002). "Some practical issues in the evaluation of heterogeneous labour market programmes by matching methods," Journal of the Royal Statistical Society, Series A, 165, pp. 59-82.

Moehling, Carolyn (1995). "The Intra-household Allocation of Resources and the Participation of Children in Household Decision-Making: Evidence from Early Twentieth Century America," mimeo., Northwestern University.

Parsons, Donald, and Claudia Goldin (1989). "Parental Altruism and Self-Interest: Child Labor Among Late Nineteenth-Century American Families," Economic Inquiry, 24, 637659.

Rajan, Raghuram, and Luigi Zingales (1998). "Financial Dependence and Growth," American Economic Review, 88, 559-586. 
Ranjan, Priya (1991). "An Economic Analysis of Child Labor," Economics Letters, 64, 99-105.

-------, ------ (2001). "Credit Constraints and the Phenomenon of Child Labor," Journal of Development Economics, vol.64.

Ravallion, Martin, and Quentin Wodon (1999). "Does Child Labor Displace Schooling? Evidence on Behavioral Responses to an Enrollment Subsidy," World Bank Working Paper No. 2116.

Rosati, Furio Camillo and Zafiris Tzannatos (2000). "Child Labor in Vietnam," mimeo., The World Bank.

Rosenbaum, P., and D. Rubin, "The Central Role of the Propensity Score in Observational Studies for Causal Effects," Biometrika, 70, 41-55.

Sianesi, Barbara. (2001). "Propensity Score Matching," available from http://ideas.uqam.ca/ideas/data/Papers/bocusug0112.html.

Srinivasan, T.N. (1996). "International Trade and Labor Standards from an Economic Perspective," in Challenges to the New World Trade Organization, Pitou van Dijck and Gerrit Faber, eds. The Hague: Kluwer.

Summers, Robert and Heston, Alan. (1991). "The Penn World Table (Mark 5): An Expanded Set of International Comparisons, 1950-1988," Quarterly Journal of Economics, 106, 327-368.

The World Bank (2001). World Development Indicators, Washington DC. 


\section{APPENDIX: Data Description and Sources}

\author{
CHILDLABOR
}

CREDIT

$\operatorname{Ln}($ GDPPC $)$

RURAL

SDGROW5

SCH_PRIF

SCH_SECF

FERT

EXP
Share of the active population between age 10 and 14 over total population between 10 and 14. Active population includes people who, during the reference period, performed "some work" for wage or salary, in cash or in kind. The notion of "some work" is interpreted as work for at least 1 hour during the reference period. Source: ILO.

Private credit by deposit money banks to GDP. Source: Beck, Demirguc-Kunt and Levine (1999).

Natural logarithm of real GDP per capita in constant dollars, chain Index, expressed in international prices, base 1985. Source: Summers-Heston, years 1960-1990.

Rural population, as \% of total population. Source: World Development Indicators, World Bank.

Standard deviation of per capita GDP growth over the previous 5 years.

Gross primary female school enrollment (\%). Gross enrollment ratio is the ratio of total enrollment, regardless of age, to the population of the age group that officially corresponds to the level of education shown. Source: World Development Indicators, World Bank.

Gross secondary female school enrollment (\%). Gross enrollment ratio is the ratio of total enrollment, regardless of age, to the population of the age group that officially corresponds to the level of education shown. Source: World Development Indicators, World Bank.

Fertility rate, total births per woman. Total fertility rate represents the number of children that would be born to a woman if she were to live to the end of her childbearing years and bear children in accordance with prevailing agespecific fertility rates. Source: World Development Indicators, World Bank.

Share of exports on GDP. Source: World Development Indicators, World Bank. 
IMP

RATIFY

LEGAL ORIGIN

GINI
Share of imports on GDP. Source: World Development Indicators, World Bank.

Dummy variable taking value of 1 if a country has ratified the ILO's Minimum Age convention (Convention no.138, ILO, Geneva, 1973).

Origin of a country's legal system. These dummies classify the legal origin of the Company Law or of Commercial Code of each country. The identified origins are five: (1) English Common Law; (2) French Commercial Code; (3) German Commercial Code; (4) Scandinavian Commercial Code; (5) Socialist/Communist laws. Source: La Porta et al. (1998), extended from "Foreign Laws: Current Sources of Basic Legislation in Jurisdictions of the World" and CIA World Factbook.

Ten-year average of the Gini coefficient over the period (e.g. 1960 is the average of 1951-1960; 1970 is the average of 1961-1970, etc.). Source: Deininger and Squire (1996). 
Figure 1: Child Labor and Access to Credit

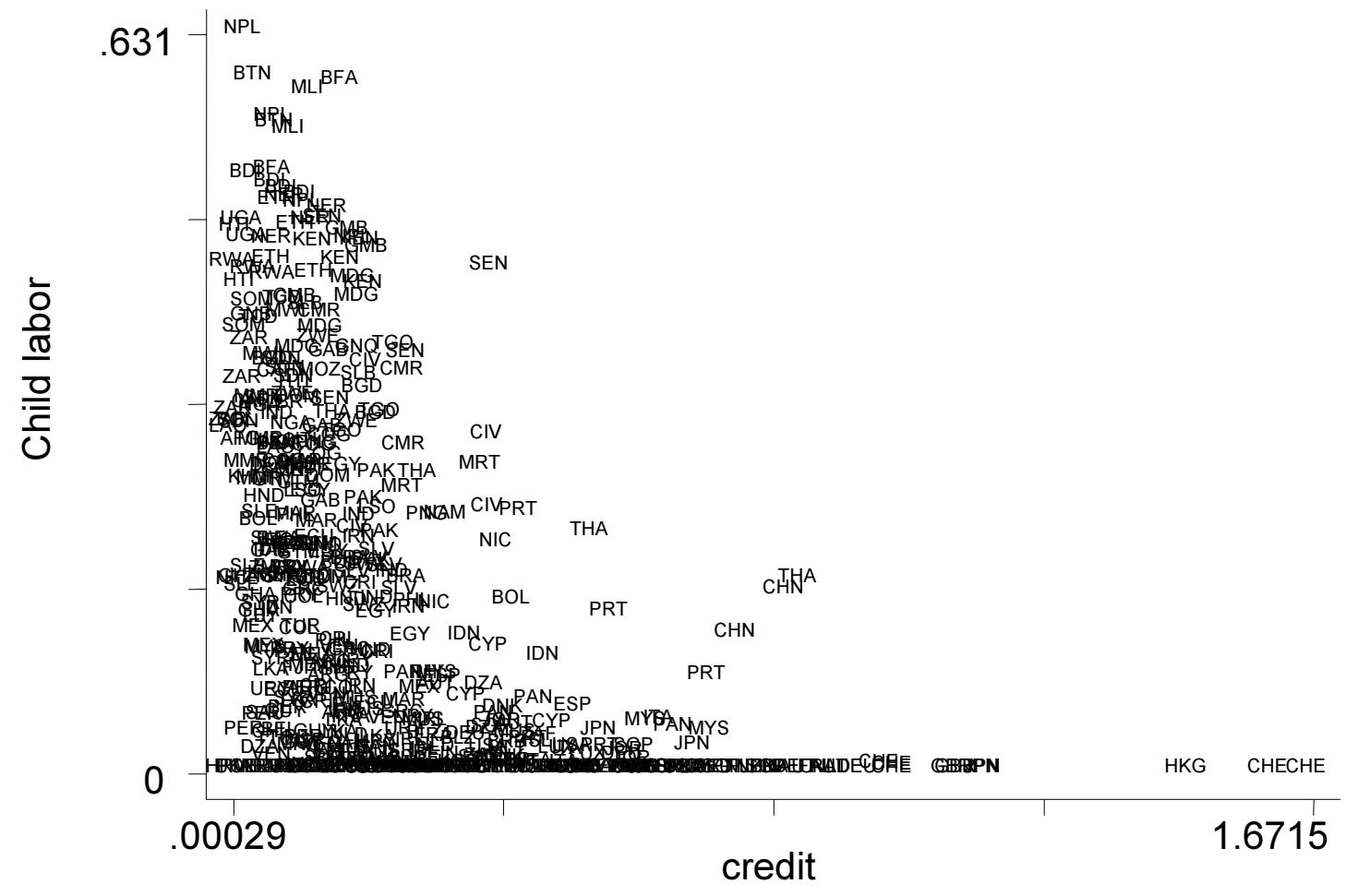


Figure 2: Child labor across regions of the world

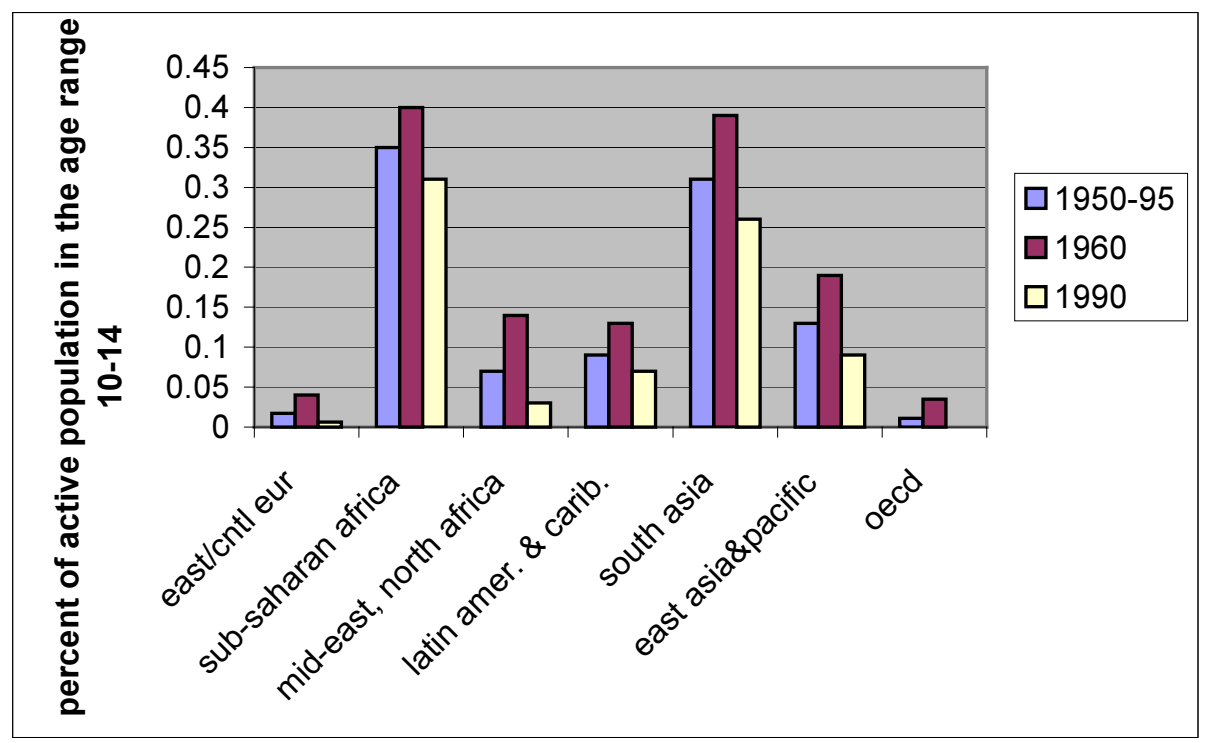


Figure 3: Child labor and access to credit over time

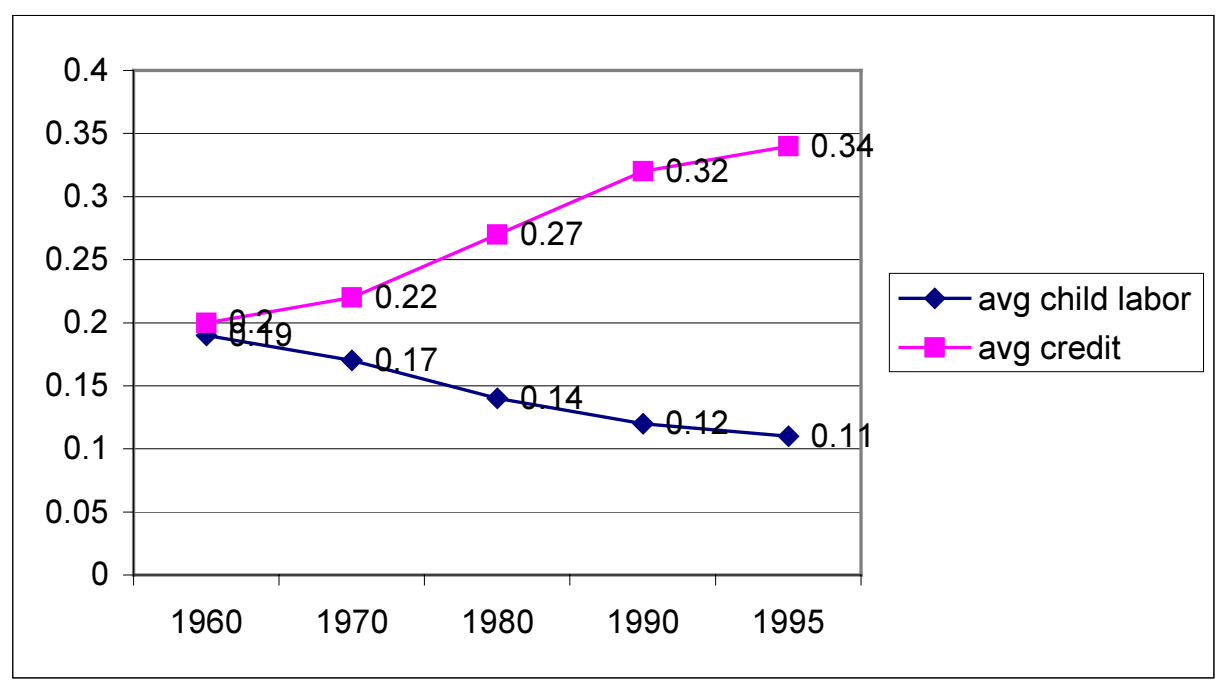


Table 1: Data Description

\begin{tabular}{lccccc}
\hline Variable & Observations & Mean & Std. Dev. & Min. & Max. \\
\hline Child labor & 860 & 0.15 & 0.17 & 0 & 0.79 \\
Credit & 482 & 0.28 & 0.25 & 0.00029 & 1.67 \\
$\begin{array}{l}\text { Standard } \\
\text { deviation of } \\
\text { income growth }\end{array}$ & 631 & 0.04 & 0.04 & 0.00059 & 0.79 \\
$\begin{array}{l}\text { log real GDP } \\
\text { per capita }\end{array}$ & 705 & 7.76 & 1.06 & 5.41 & 10.58 \\
$\begin{array}{l}\text { Percent rural } \\
\text { population }\end{array}$ & 857 & 54.58 & 24.94 & 0 & 98.2 \\
$\begin{array}{l}\text { Share of exports } \\
\text { of GDP }\end{array}$ & 630 & 32.6 & 24.38 & 1.19 & 215.38 \\
$\begin{array}{l}\text { Share of imports } \\
\text { of GDP }\end{array}$ & 634 & 37.27 & 24.74 & 1.9 & 223.65 \\
$\begin{array}{l}\text { Primary female } \\
\text { school } \\
\text { enrolment }\end{array}$ & 654 & 81.19 & 32.84 & 0.6 & 170.9 \\
$\begin{array}{l}\text { Secondary } \\
\text { female school } \\
\text { enrolment }\end{array}$ & 639 & 43.57 & 35.5 & 0 & 151.3 \\
$\begin{array}{l}\text { Gini coefficient } \\
\text { 63 }\end{array}$ & 302 & 39.22 & 10.11 & 19.5 & 62.87 \\
\hline & & & & & \\
\hline
\end{tabular}


Table 2: Correlations Among the Variables

\begin{tabular}{|c|c|c|c|c|c|c|c|c|c|c|c|}
\hline Variable & CHILD LABOR & CREDIT & SDGROW5 & LRGDPPC & RURAL & EXP & IMP & SCH_PRIF & SCH_PRIF & GINI & FERTILITY \\
\hline Child labor & 1 & & & & & & & & & & \\
\hline Credit & -0.46 & 1 & & & & & & & & & \\
\hline $\begin{array}{l}\text { Standard deviation of income } \\
\text { growth }\end{array}$ & 0.16 & -0.27 & 1 & & & & & & & & \\
\hline log real GDP per capita & -0.81 & 0.62 & -0.23 & 1 & & & & & & & \\
\hline Percent rural population & 0.75 & -0.45 & 0.13 & -0.82 & 1 & & & & & & \\
\hline Export share of GDP & -0.24 & 0.14 & 0.16 & 0.18 & -0.27 & 1 & & & & & \\
\hline Import share of GDP & -0.13 & 0.07 & 0.14 & 0.03 & -0.11 & 0.9 & 1 & & & & \\
\hline $\begin{array}{l}\text { Primary female school } \\
\text { enrolment }\end{array}$ & -0.49 & 0.23 & 0.06 & 0.48 & -0.34 & 0.15 & 0.08 & 1 & & & \\
\hline $\begin{array}{l}\text { Secondary female school } \\
\text { enrolment }\end{array}$ & -0.78 & 0.57 & -0.22 & 0.84 & -0.71 & 0.13 & 0.01 & 0.48 & 1 & & \\
\hline Gini coefficient & 0.31 & -0.33 & 0.31 & -0.38 & 0.26 & 0.04 & 0.11 & 0.11 & -0.46 & 1 & \\
\hline Fertility & 0.81 & -0.5396 & 0.1952 & -0.8433 & 0.6710 & -0.1746 & -0.0299 & -0.5618 & -0.8370 & 0.4523 & 1.0000 \\
\hline
\end{tabular}


Table 3: Base Specification (dependent variable: child labor)

\begin{tabular}{|c|c|c|c|c|c|c|}
\hline \multirow[b]{2}{*}{ Variables } & \multicolumn{3}{|c|}{ OLS } & \multicolumn{3}{|c|}{ TOBIT } \\
\hline & Basic & $\begin{array}{c}\text { with } \\
\text { CREDIT }\end{array}$ & $\begin{array}{l}\text { without } \\
\text { outliers }\end{array}$ & Basic & $\begin{array}{c}\text { with } \\
\text { CREDIT }\end{array}$ & $\begin{array}{l}\text { without } \\
\text { outliers }\end{array}$ \\
\hline & (1) & (2) & (3) & (4) & (5) & (6) \\
\hline Credit & & $\begin{array}{l}-0.033 \\
(-1.99)\end{array}$ & $\begin{array}{l}-0.04 \\
(-2.48)\end{array}$ & & $\begin{array}{c}-0.08 \\
(-2.95)\end{array}$ & $\begin{array}{c}-0.08 \\
(-2.98)\end{array}$ \\
\hline Year trend & $\begin{array}{c}-0.002 \\
(-11.91)\end{array}$ & $\begin{array}{c}-0.002 \\
(-10.51)\end{array}$ & $\begin{array}{c}-0.002 \\
(-10.84)\end{array}$ & $\begin{array}{c}-0.003 \\
(-14.35)\end{array}$ & $\begin{array}{c}-0.003 \\
(-12.17)\end{array}$ & $\begin{array}{c}-0.003 \\
(-12.27)\end{array}$ \\
\hline $\begin{array}{l}\text { log real GDP } \\
\text { per capita }\end{array}$ & $\begin{array}{c}-0.32 \\
(-7.63)\end{array}$ & $\begin{array}{l}-0.40 \\
(-7.00)\end{array}$ & $\begin{array}{c}-0.44 \\
(-8.44)\end{array}$ & $\begin{array}{c}-0.17 \\
(-4.03)\end{array}$ & $\begin{array}{c}-0.20 \\
(-3.38)\end{array}$ & $\begin{array}{c}-0.24 \\
(-4.11)\end{array}$ \\
\hline $\begin{array}{l}\text { log real GDP } \\
\text { per capita }^{2}\end{array}$ & $\begin{array}{c}0.02 \\
(7.30)\end{array}$ & $\begin{array}{c}0.02 \\
(6.82)\end{array}$ & $\begin{array}{c}0.03 \\
(8.18)\end{array}$ & $\begin{array}{l}0.008 \\
(3.13)\end{array}$ & $\begin{array}{c}0.01 \\
(2.81)\end{array}$ & $\begin{array}{c}0.01 \\
(3.47)\end{array}$ \\
\hline $\begin{array}{l}\text { Percent rural } \\
\text { population }\end{array}$ & $\begin{array}{c}0.00022 \\
(1.24)\end{array}$ & $\begin{array}{c}0.00036 \\
(1.68)\end{array}$ & $\begin{array}{c}0.00032 \\
(1.48)\end{array}$ & $\begin{array}{c}0.0000642 \\
(0.29)\end{array}$ & $\begin{array}{c}0.00033 \\
(1.25)\end{array}$ & $\begin{array}{c}0.00031 \\
(1.19)\end{array}$ \\
\hline $\begin{array}{l}\text { Child labor in } \\
1950\end{array}$ & $\begin{array}{c}0.69 \\
(23.27)\end{array}$ & $\begin{array}{c}0.63 \\
(14.99)\end{array}$ & $\begin{array}{c}0.62 \\
(14.98)\end{array}$ & $\begin{array}{c}0.76 \\
(27.10)\end{array}$ & $\begin{array}{c}0.69 \\
(18.29)\end{array}$ & $\begin{array}{c}0.68 \\
(18.06)\end{array}$ \\
\hline Constant & $\begin{array}{c}5.73 \\
(13.46)\end{array}$ & $\begin{array}{c}5.44 \\
(12.86)\end{array}$ & $\begin{array}{c}5.63 \\
(13.68)\end{array}$ & $\begin{array}{c}6.84 \\
(14.39)\end{array}$ & $\begin{array}{c}6.30 \\
(12.66)\end{array}$ & $\begin{array}{c}6.45 \\
(13.04)\end{array}$ \\
\hline $\mathrm{N}$ & 703 & 474 & 469 & 703 & 474 & 469 \\
\hline $\mathrm{R}^{2}$ & 0.9276 & 0.9164 & 0.9191 & . & . & . \\
\hline
\end{tabular}

Notes: t-statistics in parentheses. Standard errors are corrected for heteroscedasticity and clustering within countries. Marginal coefficients are reported for Tobit estimates. 
Table 4: Splitting by Income Levels (dependent variable: child labor)

\begin{tabular}{|c|c|c|c|c|}
\hline \multirow[b]{2}{*}{ Variables } & \multicolumn{2}{|c|}{ OLS } & \multicolumn{2}{|c|}{ TOBIT } \\
\hline & $\begin{array}{c}\text { Low } \\
\text { income }\end{array}$ & $\begin{array}{c}\text { High } \\
\text { income }\end{array}$ & $\begin{array}{c}\text { Low } \\
\text { income }\end{array}$ & $\begin{array}{c}\text { High } \\
\text { income }\end{array}$ \\
\hline & (2) & (3) & (5) & (6) \\
\hline Credit & $\begin{array}{c}-0.14 \\
(-2.63)\end{array}$ & $\begin{array}{l}-0.024 \\
(-2.22)\end{array}$ & $\begin{array}{l}-0.13 \\
(-2.41)\end{array}$ & $\begin{array}{l}-0.035 \\
(-2.64)\end{array}$ \\
\hline Year trend & $\begin{array}{l}-0.002 \\
(-7.00)\end{array}$ & $\begin{array}{l}-0.001 \\
(-5.57)\end{array}$ & $\begin{array}{l}-0.002 \\
(-7.36)\end{array}$ & $\begin{array}{r}-0.0015 \\
(-7.18)\end{array}$ \\
\hline $\begin{array}{l}\text { log real GDP } \\
\text { per capita }\end{array}$ & $\begin{array}{l}-0.069 \\
(-0.35)\end{array}$ & $\begin{array}{l}-0.56 \\
(-3.6)\end{array}$ & $\begin{array}{c}-0.08 \\
(-0.43)\end{array}$ & $\begin{array}{c}0.06 \\
(0.34)\end{array}$ \\
\hline $\begin{array}{l}\text { log real GDP } \\
\text { per capita }\end{array}$ & $\begin{array}{c}0.0023 \\
(0.16)\end{array}$ & $\begin{array}{c}0.03 \\
(3.58)\end{array}$ & $\begin{array}{l}0.003 \\
(0.25)\end{array}$ & $\begin{array}{c}-0.0047 \\
(0.44)\end{array}$ \\
\hline $\begin{array}{l}\text { Percent rural } \\
\text { population }\end{array}$ & $\begin{array}{c}0.0008 \\
(1.59)\end{array}$ & $\begin{array}{c}0.00006 \\
(0.36)\end{array}$ & $\begin{array}{l}0.003 \\
(1.73)\end{array}$ & $\begin{array}{c}0.0001 \\
(0.78)\end{array}$ \\
\hline $\begin{array}{l}\text { Child labor in } \\
1950\end{array}$ & $\begin{array}{c}0.74 \\
(14.8)\end{array}$ & $\begin{array}{c}0.45 \\
(5.76)\end{array}$ & $\begin{array}{c}0.74 \\
(14.76)\end{array}$ & $\begin{array}{l}0.33 \\
(7.9)\end{array}$ \\
\hline Constant & $\begin{array}{l}4.43 \\
(4.8)\end{array}$ & $\begin{array}{c}5.31 \\
(5.25)\end{array}$ & $\begin{array}{l}4.72 \\
(5.1)\end{array}$ & $\begin{array}{l}4.78 \\
(2.82)\end{array}$ \\
\hline $\mathrm{N}$ & 209 & 265 & 209 & 265 \\
\hline $\mathrm{R}^{2}$ & 0.8813 & 0.69 & . & t \\
\hline
\end{tabular}

Notes: t-statistics in parentheses. Standard errors are corrected for heteroscedasticity and clustering within countries. Marginal coefficients are reported for Tobit estimates. The sample is split at the mean level of logincome (7.75) 


\begin{tabular}{|c|c|c|c|c|c|c|}
\hline & \multicolumn{3}{|c|}{ OLS } & \multicolumn{3}{|c|}{ TOBIT } \\
\hline & & $\begin{array}{c}\text { low } \\
\text { CREDIT }\end{array}$ & $\begin{array}{c}\text { high } \\
\text { CREDIT }\end{array}$ & & $\begin{array}{c}\text { low } \\
\text { CREDIT }\end{array}$ & $\begin{array}{c}\text { high } \\
\text { CREDIT }\end{array}$ \\
\hline & (1) & (2) & (3) & (4) & (5) & (6) \\
\hline Credit & $\begin{array}{c}-0.03 \\
(-1.82)\end{array}$ & & & $\begin{array}{c}-0.08 \\
(-3.00)\end{array}$ & & \\
\hline $\begin{array}{l}\text { Standard } \\
\text { deviation of } \\
\text { income growth }\end{array}$ & $\begin{array}{c}0.19 \\
(2.63)\end{array}$ & $\begin{array}{c}0.21 \\
(2.83)\end{array}$ & $\begin{array}{c}0.07 \\
(0.61)\end{array}$ & $\begin{array}{c}0.20 \\
(2.68)\end{array}$ & $\begin{array}{c}0.18 \\
(2.40)\end{array}$ & $\begin{array}{c}0.07 \\
(1.00)\end{array}$ \\
\hline Year trend & $\begin{array}{l}-0.002 \\
(-9.83)\end{array}$ & $\begin{array}{c}-0.002 \\
(-10.68)\end{array}$ & $\begin{array}{l}-0.001 \\
(-3.93)\end{array}$ & $\begin{array}{l}-0.0026 \\
(-11.56)\end{array}$ & $\begin{array}{l}-0.002 \\
(-1.42)\end{array}$ & $\begin{array}{l}-0.001 \\
(-5.36)\end{array}$ \\
\hline $\begin{array}{l}\text { log real GDP } \\
\text { per capita }\end{array}$ & $\begin{array}{c}-0.40 \\
(-7.13)\end{array}$ & $\begin{array}{c}-0.27 \\
(-4.52)\end{array}$ & $\begin{array}{c}-0.70 \\
(-4.79)\end{array}$ & $\begin{array}{c}-0.20 \\
(-3.34)\end{array}$ & $\begin{array}{c}-0.20 \\
(-3.18)\end{array}$ & $\begin{array}{c}-0.21 \\
(-2.57)\end{array}$ \\
\hline $\begin{array}{l}\text { log real GDP } \\
\text { per capita }^{2}\end{array}$ & $\begin{array}{c}0.02 \\
(6.98)\end{array}$ & $\begin{array}{c}0.02 \\
(4.27)\end{array}$ & $\begin{array}{c}0.04 \\
(4.76)\end{array}$ & $\begin{array}{c}0.01 \\
(2.78)\end{array}$ & $\begin{array}{c}0.01 \\
(2.77)\end{array}$ & $\begin{array}{l}0.01 \\
(2.32)\end{array}$ \\
\hline $\begin{array}{l}\text { Percent rural } \\
\text { population }\end{array}$ & $\begin{array}{l}0.0004 \\
(1.73)\end{array}$ & $\begin{array}{c}0.00058 \\
(2.01)\end{array}$ & $\begin{array}{c}0.00033 \\
(1.38)\end{array}$ & $\begin{array}{c}0.00031 \\
(1.21)\end{array}$ & $\begin{array}{c}0.00043 \\
(1.44)\end{array}$ & $\begin{array}{c}0.00029 \\
(1.57)\end{array}$ \\
\hline $\begin{array}{l}\text { Child labor in } \\
1950\end{array}$ & $\begin{array}{c}0.64 \\
(14.40)\end{array}$ & $\begin{array}{c}0.72 \\
(20.57)\end{array}$ & $\begin{array}{c}0.29 \\
(3.59)\end{array}$ & $\begin{array}{c}0.69 \\
(17.86)\end{array}$ & $\begin{array}{c}0.75 \\
(20.90)\end{array}$ & $\begin{array}{c}0.20 \\
(5.14)\end{array}$ \\
\hline Constant & $\begin{array}{c}5.44 \\
(12.47)\end{array}$ & $\begin{array}{c}5.36 \\
(11.91)\end{array}$ & $\begin{array}{c}5.62 \\
(5.14)\end{array}$ & $\begin{array}{c}6.07 \\
(12.04)\end{array}$ & $\begin{array}{c}5.72 \\
(12.20)\end{array}$ & $\begin{array}{c}7.17 \\
(4.98)\end{array}$ \\
\hline $\mathrm{N}$ & 457 & 301 & 156 & 457 & 301 & 156 \\
\hline $\mathrm{R}^{2}$ & 0.9182 & 0.9270 & 0.9304 & . & . & . \\
\hline
\end{tabular}

Notes: t-statistics in parentheses. Standard errors are corrected for heteroscedasticity and clustering within countries. Marginal coefficients are reported for Tobit estimates. 
Table 6: Robustness Checks (OLS, dependent variable: child labor)

\begin{tabular}{|c|c|c|c|c|c|c|c|c|c|}
\hline & (1) & (2) & (3) & (4) & (5) & (6) & (7) & (8) & (9) \\
\hline Credit & $\begin{array}{l}-0.024 \\
(-1.51)\end{array}$ & $\begin{array}{l}-0.029 \\
(-1.83)\end{array}$ & $\begin{array}{l}-0.027 \\
(-1.76)\end{array}$ & $\begin{array}{l}-0.020 \\
(-1.43)\end{array}$ & $\begin{array}{l}-0.035 \\
(-1.64)\end{array}$ & $\begin{array}{l}-0.031 \\
(-1.82)\end{array}$ & $\begin{array}{l}-0.033 \\
(-1.90)\end{array}$ & $\begin{array}{l}-0.032 \\
(-1.92)\end{array}$ & $\begin{array}{c}-0.02 \\
(-1.35)\end{array}$ \\
\hline Year trend & $\begin{array}{c}-0.002 \\
(-10.51)\end{array}$ & $\begin{array}{l}-0.002 \\
(-7.88)\end{array}$ & $\begin{array}{l}-0.001 \\
(-4.75)\end{array}$ & $\begin{array}{l}-0.001 \\
(-5.90)\end{array}$ & $\begin{array}{l}-0.002 \\
(-7.75)\end{array}$ & $\begin{array}{c}-0.002 \\
(-10.47)\end{array}$ & $\begin{array}{c}-0.002 \\
(-10.49)\end{array}$ & $\begin{array}{l}-0.001 \\
(-5.56)\end{array}$ & $\begin{array}{l}-0.002 \\
(-7.77)\end{array}$ \\
\hline $\begin{array}{l}\text { log real GDP } \\
\text { per capita }\end{array}$ & $\begin{array}{c}-0.38 \\
(-6.05)\end{array}$ & $\begin{array}{l}-0.40 \\
(-6.80)\end{array}$ & $\begin{array}{l}-0.48 \\
(-8.33)\end{array}$ & $\begin{array}{c}-0.38 \\
(-7.23)\end{array}$ & $\begin{array}{c}-0.40 \\
(-6.75)\end{array}$ & $\begin{array}{c}-0.41 \\
(-6.64)\end{array}$ & $\begin{array}{c}-0.41 \\
(-6.73)\end{array}$ & $\begin{array}{c}-0.52 \\
(-7.35)\end{array}$ & $\begin{array}{c}-0.42 \\
(-6.09)\end{array}$ \\
\hline $\begin{array}{l}\text { log real GDP } \\
\text { per capita }^{2}\end{array}$ & $\begin{array}{c}0.02 \\
(5.98)\end{array}$ & $\begin{array}{c}0.02 \\
(6.56)\end{array}$ & $\begin{array}{c}0.03 \\
(8.13)\end{array}$ & $\begin{array}{c}0.02 \\
(7.09)\end{array}$ & $\begin{array}{c}0.02 \\
(6.48)\end{array}$ & $\begin{array}{c}0.02 \\
(6.48)\end{array}$ & $\begin{array}{c}0.02 \\
(6.58)\end{array}$ & $\begin{array}{c}0.03 \\
(7.23)\end{array}$ & $\begin{array}{l}0.025 \\
(5.88)\end{array}$ \\
\hline $\begin{array}{l}\text { Percent rural } \\
\text { population }\end{array}$ & $\begin{array}{c}0.00036 \\
(1.64)\end{array}$ & $\begin{array}{c}0.00037 \\
(1.75)\end{array}$ & $\begin{array}{c}0.00033 \\
(1.56)\end{array}$ & $\begin{array}{c}0.00032 \\
(1.55)\end{array}$ & $\begin{array}{c}0.00042 \\
(1.71)\end{array}$ & $\begin{array}{c}0.00037 \\
(1.69)\end{array}$ & $\begin{array}{c}0.00037 \\
(1.68)\end{array}$ & $\begin{array}{c}0.00028 \\
(0.98)\end{array}$ & $\begin{array}{c}0.0004 \\
(1.46)\end{array}$ \\
\hline $\begin{array}{l}\text { Child labor in } \\
1950\end{array}$ & $\begin{array}{c}0.62 \\
(13.23)\end{array}$ & $\begin{array}{c}0.60 \\
(12.60)\end{array}$ & $\begin{array}{c}0.57 \\
(11.18)\end{array}$ & $\begin{array}{c}0.59 \\
(13.37)\end{array}$ & $\begin{array}{c}0.64 \\
(13.67)\end{array}$ & $\begin{array}{c}0.63 \\
(14.95)\end{array}$ & $\begin{array}{c}0.63 \\
(14.95)\end{array}$ & $\begin{array}{c}0.50 \\
(8.76)\end{array}$ & $\begin{array}{c}0.58 \\
(13.2)\end{array}$ \\
\hline $\begin{array}{l}\text { East Asia and } \\
\text { Pacific }\end{array}$ & $\begin{array}{l}0.003 \\
(0.32)\end{array}$ & & & & & & & & \\
\hline $\begin{array}{l}\text { Eastern and } \\
\text { Central } \\
\text { Europe }\end{array}$ & $\begin{array}{c}0.02 \\
(1.24)\end{array}$ & & & & & & & & \\
\hline $\begin{array}{l}\text { Latin America } \\
\text { and Caribbean }\end{array}$ & $\begin{array}{c}0.02 \\
(1.65)\end{array}$ & & & & & & & & \\
\hline $\begin{array}{l}\text { Mid-East and } \\
\text { North Africa }\end{array}$ & $\begin{array}{l}0.001 \\
(0.08)\end{array}$ & & & & & & & & \\
\hline South Asia & $\begin{array}{c}0.02 \\
(0.94)\end{array}$ & & & & & & & & \\
\hline $\begin{array}{l}\text { Sub-Saharan } \\
\text { Africa }\end{array}$ & $\begin{array}{c}0.04 \\
(2.39)\end{array}$ & & & & & & & & \\
\hline $\begin{array}{l}\text { Primary } \\
\text { female school }\end{array}$ & & $\begin{array}{c}-0.00034 \\
(-1.63)\end{array}$ & & & & & & & \\
\hline $\begin{array}{l}\text { Secondary } \\
\text { female school }\end{array}$ & & & $\begin{array}{c}-0.00053 \\
(-3.04)\end{array}$ & & & & & & \\
\hline Fertility & & & & $\begin{array}{c}0.01 \\
(3.40)\end{array}$ & & & & & \\
\hline $\begin{array}{l}\text { Legal origin } \\
\text { dummies }\end{array}$ & & & & & Yes & & & & \\
\hline $\begin{array}{l}\text { Export share } \\
\text { of GDP }\end{array}$ & & & & & & $\begin{array}{c}0.00758 \\
(0.77)\end{array}$ & & & \\
\hline $\begin{array}{l}\text { Import share } \\
\text { of GDP }\end{array}$ & & & & & & & $\begin{array}{l}0.011 \\
(1.16)\end{array}$ & & \\
\hline $\begin{array}{l}\text { Gini } \\
\text { coefficient }\end{array}$ & & & & & & & & $\begin{array}{c}0.00051 \\
(1.15)\end{array}$ & \\
\hline $\begin{array}{l}\text { Ratified ILO } \\
\text { Convention }\end{array}$ & & & & & & & & & $\begin{array}{l}-0.0067 \\
(-0.865)\end{array}$ \\
\hline Constant & $\begin{array}{c}5.77 \\
(12.28)\end{array}$ & $\begin{array}{c}5.07 \\
(9.71)\end{array}$ & $\begin{array}{c}4.56 \\
(7.97)\end{array}$ & $\begin{array}{c}4.39 \\
(8.25)\end{array}$ & $\begin{array}{c}5.39 \\
(10.19)\end{array}$ & $\begin{array}{c}5.66 \\
(12.48)\end{array}$ & $\begin{array}{c}5.70 \\
(12.54)\end{array}$ & $\begin{array}{c}4.71 \\
(9.77)\end{array}$ & $\begin{array}{c}6.53 \\
(9.62)\end{array}$ \\
\hline $\mathrm{N}$ & 474 & 414 & 408 & 472 & 471 & 451 & 455 & 243 & 338 \\
\hline $\mathrm{R}^{2}$ & 0.9217 & 0.9221 & 0.9249 & 0.9205 & 0.9177 & 0.9142 & 0.9149 & 0.8970 & 0.90 \\
\hline
\end{tabular}

Notes: t-statistics in parentheses. Standard errors are corrected for heteroscedasticity and clustering within countries. 
Table 7: Robustness Checks (Tobit, dependent variable: child labor)

\begin{tabular}{|c|c|c|c|c|c|c|c|c|c|}
\hline & $\overline{(11)}$ & $\overline{(2)}$ & $\overline{(3)}$ & $\overline{~(4)}$ & $\overline{~(5)}$ & (6) & (7) & $\overline{(8)}$ & $\overline{~(9)}$ \\
\hline Credit & -0.07 & -0.08 & -0.06 & -0.05 & -0.09 & -0.08 & -0.08 & -0.07 & -0.09 \\
\hline & $(-2.77)$ & $(-2.82)$ & $(-2.51)$ & $(-2.37)$ & $(-3.17)$ & $(-2.77)$ & $(-2.91)$ & $(-2.47)$ & $(-2.76)$ \\
\hline Year trend & -0.003 & -0.002 & -0.002 & -0.002 & -0.002 & -0.003 & -0.003 & -0.002 & -0.003 \\
\hline & $(-12.38)$ & $(-9.58)$ & $(-6.21)$ & $(-8.79)$ & $(-10.23)$ & $(-11.98)$ & $(-12.14)$ & $(-6.15)$ & $(-8.07)$ \\
\hline $\begin{array}{l}\text { log real GDP } \\
\text { per capita }\end{array}$ & $\begin{array}{c}-0.16 \\
(-2.54)\end{array}$ & $\begin{array}{c}-0.22 \\
(-3.52)\end{array}$ & $\begin{array}{c}-0.28 \\
(-4.80)\end{array}$ & $\begin{array}{c}-0.21 \\
(-3.67)\end{array}$ & $\begin{array}{c}-0.21 \\
(-3.25)\end{array}$ & $\begin{array}{c}-0.21 \\
(-3.11)\end{array}$ & $\begin{array}{c}-0.21 \\
(-3.23)\end{array}$ & $\begin{array}{c}-0.27 \\
(-3.54)\end{array}$ & $\begin{array}{c}-0.11 \\
(-1.49)\end{array}$ \\
\hline $\begin{array}{l}\text { log real GDP } \\
\text { per capita }\end{array}$ & $\begin{array}{l}0.008 \\
(2.15)\end{array}$ & $\begin{array}{c}0.01 \\
(2.94)\end{array}$ & $\begin{array}{c}0.02 \\
(4.24)\end{array}$ & $\begin{array}{c}0.01 \\
(3.18)\end{array}$ & $\begin{array}{c}0.01 \\
(2.72)\end{array}$ & $\begin{array}{c}0.01 \\
(2.58)\end{array}$ & $\begin{array}{c}0.01 \\
(2.71)\end{array}$ & $\begin{array}{c}0.01 \\
(3.06)\end{array}$ & $\begin{array}{l}0.004 \\
(0.88)\end{array}$ \\
\hline $\begin{array}{l}\text { Percent rural } \\
\text { population }\end{array}$ & $\begin{array}{c}0.00034 \\
(1.38)\end{array}$ & $\begin{array}{c}0.00034 \\
(1.30)\end{array}$ & $\begin{array}{c}0.00029 \\
(1.23)\end{array}$ & $\begin{array}{c}0.00028 \\
(1.11)\end{array}$ & $\begin{array}{c}0.00053 \\
(1.79)\end{array}$ & $\begin{array}{c}0.00032 \\
(1.24)\end{array}$ & $\begin{array}{c}0.00030 \\
(1.19)\end{array}$ & $\begin{array}{c}0.00031 \\
(0.90)\end{array}$ & $\begin{array}{c}0.0004 \\
(1.1)\end{array}$ \\
\hline $\begin{array}{l}\text { Child labor } \\
\text { in } 1950\end{array}$ & $\begin{array}{c}0.67 \\
(16.66)\end{array}$ & $\begin{array}{c}0.66 \\
(15.94)\end{array}$ & $\begin{array}{c}0.61 \\
(14.71)\end{array}$ & $\begin{array}{c}0.66 \\
(17.39)\end{array}$ & $\begin{array}{c}0.68 \\
(16.95)\end{array}$ & $\begin{array}{c}0.69 \\
(18.23)\end{array}$ & $\begin{array}{c}0.70 \\
(18.33)\end{array}$ & $\begin{array}{c}0.56 \\
(12.50)\end{array}$ & $\begin{array}{c}0.65 \\
(15.77)\end{array}$ \\
\hline $\begin{array}{l}\text { East Asia } \\
\text { and Pacific }\end{array}$ & $\begin{array}{l}-0.002 \\
(-0.12)\end{array}$ & & & & & & & & \\
\hline $\begin{array}{l}\text { Eastern and } \\
\text { Central } \\
\text { Europe }\end{array}$ & $\begin{array}{c}-0.04 \\
(-1.16)\end{array}$ & & & & & & & & \\
\hline $\begin{array}{l}\text { Latin } \\
\text { America and } \\
\text { Caribbean }\end{array}$ & $\begin{array}{l}0.007 \\
(0.61)\end{array}$ & & & & & & & & \\
\hline $\begin{array}{l}\text { Mid-East } \\
\text { and North } \\
\text { Africa }\end{array}$ & $\begin{array}{l}-0.009 \\
(-0.75)\end{array}$ & & & & & & & & \\
\hline South Asia & $\begin{array}{l}0.004 \\
(0.18)\end{array}$ & & & & & & & & \\
\hline $\begin{array}{l}\text { Sub-Saharan } \\
\text { Africa }\end{array}$ & $\begin{array}{c}0.03 \\
(1.88)\end{array}$ & & & & & & & & \\
\hline $\begin{array}{l}\text { Primary } \\
\text { female } \\
\text { school }\end{array}$ & & $\begin{array}{c}-0.00019 \\
(-1.00)\end{array}$ & & & & & & & \\
\hline $\begin{array}{l}\text { Secondary } \\
\text { female } \\
\text { school }\end{array}$ & & & $\begin{array}{c}-0.00090 \\
(-4.75)\end{array}$ & & & & & & \\
\hline Fertility & & & & $\begin{array}{l}0.009 \\
(3.42)\end{array}$ & & & & & \\
\hline $\begin{array}{l}\text { Legal origin } \\
\text { dummies }\end{array}$ & & & & & Yes & & & & \\
\hline $\begin{array}{l}\text { Export share } \\
\text { of GDP }\end{array}$ & & & & & & $\begin{array}{c}0.00011 \\
(0.71)\end{array}$ & & & \\
\hline $\begin{array}{l}\text { Import share } \\
\text { of GDP }\end{array}$ & & & & & & & $\begin{array}{c}0.00016 \\
(1.27)\end{array}$ & & \\
\hline $\begin{array}{l}\text { Gini } \\
\text { coefficient }\end{array}$ & & & & & & & & $\begin{array}{c}0.00069 \\
(1.34)\end{array}$ & \\
\hline $\begin{array}{l}\text { Ratified ILO } \\
\text { Convention }\end{array}$ & & & & & & & & & $\begin{array}{c}-0.004 \\
(0.44)\end{array}$ \\
\hline Constant & $\begin{array}{c}6.13 \\
(12.38)\end{array}$ & $\begin{array}{c}5.99 \\
(9.94)\end{array}$ & $\begin{array}{c}4.86 \\
(7.92)\end{array}$ & $\begin{array}{c}5.41 \\
(9.70)\end{array}$ & $\begin{array}{c}5.89 \\
(10.72)\end{array}$ & $\begin{array}{c}6.50 \\
(12.32)\end{array}$ & $\begin{array}{c}6.61 \\
(12.43)\end{array}$ & $\begin{array}{c}5.25 \\
(7.59)\end{array}$ & $\begin{array}{l}7.43 \\
(8.3)\end{array}$ \\
\hline $\mathrm{N}$ & 474 & 414 & 408 & 472 & 471 & 451 & 455 & 243 & 338 \\
\hline
\end{tabular}

Notes: t-statistics in parentheses. Standard errors are corrected for heteroscedasticity and clustering within countries. Marginal coefficients are reported. 
Table 8: Fixed-Effects OLS and Random-Effects Tobit Models

\begin{tabular}{|c|c|c|c|c|c|c|}
\hline Variable & $\begin{array}{c}\text { Fixed-Effects } \\
\text { OLS }\end{array}$ & $\begin{array}{c}\text { Fixed- } \\
\text { Effects OLS } \\
\text { Low-Income } \\
\text { Countries }\end{array}$ & $\begin{array}{l}\text { Fixed-Effects } \\
\text { OLS High- } \\
\text { Income } \\
\text { Countries } \\
\end{array}$ & $\begin{array}{c}\text { Random- } \\
\text { Effects Tobit }\end{array}$ & $\begin{array}{c}\text { Random - } \\
\text { Effects Tobit } \\
\text { Low-Income } \\
\text { Countries }\end{array}$ & $\begin{array}{c}\text { Random - } \\
\text { Effects Tobit } \\
\text { High-Income } \\
\text { Countries }\end{array}$ \\
\hline Credit & $\begin{array}{l}0.0204 \\
(1.99)\end{array}$ & $\begin{array}{c}-0.062 \\
(-1.980)\end{array}$ & $\begin{array}{c}0.015 \\
(1.780)\end{array}$ & $\begin{array}{l}-0.019 \\
(-1.42)\end{array}$ & $\begin{array}{c}-0.077 \\
(-2.910)\end{array}$ & $\begin{array}{c}-0.010 \\
(-1.050)\end{array}$ \\
\hline Year trend & $\begin{array}{c}-0.002 \\
(10.02)\end{array}$ & $\begin{array}{c}-0.003 \\
(-7.790)\end{array}$ & $\begin{array}{c}-0.001 \\
(-6.010)\end{array}$ & $\begin{array}{l}-0.0026 \\
(20.05)\end{array}$ & $\begin{array}{c}-0.001 \\
(-3.520)\end{array}$ & $\begin{array}{c}-0.001 \\
(-10.230)\end{array}$ \\
\hline log real GDP per capita & $\begin{array}{l}-0.21 \\
(-6.02)\end{array}$ & $\begin{array}{c}0.086 \\
(0.690)\end{array}$ & $\begin{array}{c}-0.370 \\
(-4.220)\end{array}$ & $\begin{array}{l}-0.083 \\
(-3.28)\end{array}$ & $\begin{array}{c}0.207 \\
(1.560)\end{array}$ & $\begin{array}{c}-0.003 \\
(-0.020)\end{array}$ \\
\hline log real GDP per capita ${ }^{2}$ & $\begin{array}{l}0.013 \\
(6.18)\end{array}$ & $\begin{array}{c}-0.006 \\
(-0.680)\end{array}$ & $\begin{array}{c}0.022 \\
(4.310)\end{array}$ & $\begin{array}{l}0.0045 \\
(2.71)\end{array}$ & $\begin{array}{c}-0.017 \\
(-1.770)\end{array}$ & $\begin{array}{c}-0.001 \\
(-0.130)\end{array}$ \\
\hline Percent rural population & $\begin{array}{l}0.0014 \\
(4.84)\end{array}$ & $\begin{array}{c}0.001 \\
(1.900)\end{array}$ & $\begin{array}{c}0.001 \\
(4.540)\end{array}$ & $\begin{array}{l}0.0006 \\
(3.79)\end{array}$ & $\begin{array}{c}0.003 \\
(8.050)\end{array}$ & $\begin{array}{c}0.002 \\
(13.610)\end{array}$ \\
\hline
\end{tabular}

Notes: t-statistics in parentheses. 
Table 9: Propensity Score Estimates of the Effect of Credit on Child Labor

\begin{tabular}{lccc}
\hline $\begin{array}{l}\text { Estimated } \\
\text { Treatment Effect }\end{array}$ & Base Model & $\begin{array}{c}\text { Controlling for } \\
\text { Initial Child Labor }\end{array}$ & $\begin{array}{c}\text { Controlling for } \\
\text { Lagged Child } \\
\text { Labor }\end{array}$ \\
\hline & & & \\
$1960-1995$ & -0.0133 & -0.01156 & -0.00926 \\
& $(-2.0826)$ & $(-2.1573)$ & $(-1.9835)$ \\
\hline
\end{tabular}

Notes: t-statistics in parentheses. The treatment effects are estimated through kernel propensity score matching, with standard errors estimated via a bootstrap using Sianesi (2001). The estimates in column (1) control for log real GDP per capita, log real GDP per capita ${ }^{2}$, percent rural population, and age-dependency ratio. In column (2) we also control for child labor in 1950. In column (3), we control for lagged child labor. 
Table 10: Dose-Response Estimates of the Effect of Credit on Child Labor

\begin{tabular}{|c|c|c|c|c|c|}
\hline & & & & tment & \\
\hline & & 1 & 2 & 3 & 4 \\
\hline & 1 & $\mathrm{x}$ & $\begin{array}{l}0.0072 \\
(0.986)\end{array}$ & $\begin{array}{l}0.0064 \\
(0.744)\end{array}$ & $\begin{array}{l}0.0056 \\
(0.528)\end{array}$ \\
\hline Counterfactual & 2 & $\begin{array}{c}-0.0022 \\
(-0.344)\end{array}$ & $\mathrm{x}$ & $\begin{array}{l}0.0020 \\
(0.313)\end{array}$ & $\begin{array}{l}0.0049 \\
(0.613)\end{array}$ \\
\hline & 3 & $\begin{array}{l}-0.0078 \\
(-1.345)\end{array}$ & $\begin{array}{l}-0.0144 \\
(-3.000)\end{array}$ & $x$ & $\begin{array}{l}0.0079 \\
(1.145)\end{array}$ \\
\hline & 4 & $\begin{array}{l}-0.0216 \\
(-4.154)\end{array}$ & $\begin{array}{l}-0.0207 \\
(-4.814)\end{array}$ & $\begin{array}{l}-0.0158 \\
(-5.097)\end{array}$ & $\mathrm{x}$ \\
\hline
\end{tabular}

Notes: t-statistics in parentheses (computed via a bootstrap). Treatments 1 to 4 correspond to quartiles 1 to 4 of credit. The cell corresponding to row $i$ and column $j$ corresponds to the estimated effect on child labor of moving from treatment $i$ to treatment $j$. The propensity score controls for the variables in the basic specification, Table 3. 